\title{
EXPERIMENTAL AND NUMERICAL STUDY OF HOT-STEEL-PLATE FLATNESS
}

\section{EKSPERIMENTALNI IN NUMERIČNI ŠTUDIJ RAVNOSTI VROČIH PLOŠČ IZ JEKLA}

\author{
Jozef Hrabovský ${ }^{1}$, Michal Pohanka ${ }^{1}$, Pil Jong Lee ${ }^{2}$, Jong Hoon Kang ${ }^{2}$ \\ ${ }^{1}$ Heat Transfer and Fluid Flow Laboratory, Faculty of Mechanical Engineering, Brno University of Technology, Technická 2, 61669 Brno, \\ Czech Republic \\ ${ }^{2}$ POSCO, Rolling Technology \& Process Control Research Group, 1, Geodong-dong, Nam-gu, Pohang, Gyeongbuk 790-785, Korea \\ hrabovsky@fme.vutbr.cz
}

Prejem rokopisa - received: 2014-07-31; sprejem za objavo - accepted for publication: 2015-02-10

doi:10.17222/mit.2014.153

\begin{abstract}
One aspect of the steel-product quality is the flatness of a steel plate. This is one of the reasons why it is important to describe and understand the process of steel-plate deformation during the cooling process. The temperature distribution has the largest impact on the deformation of a strip. The temperature distribution is affected by the cooling process. The cooling homogeneity or inhomogeneity is the most important factor influencing the final flatness of a cooled strip or steel plate. Inhomogeneous cooling can lead to large differences in the thermal distribution inside the material and also to high deformations. The cooling homogeneity is mainly influenced by the water distribution in the cooling section. The goal of this paper is to experimentally and numerically study and describe the deformation process of a hot steel plate during the cooling process. To meet these goals, experimental measurements of a cooled steel plate were carried out and the boundary conditions and temperature field were obtained. Based on this data, two numerical models were created. The first numerical model focused on the cooling process, the thermal-field simulation and the input-data preparation for the next step. In the next step, the second numerical model was generated using the finite-element method and an analysis of the structure and deformation of the steel plate was simulated. The description of the shape deformation of cooled steel plates should lead to an improved flatness of final products.

Keywords: cooling process, deformation, flatness, numerical simulation
\end{abstract}

Eden od vidikov kvalitete izdelka iz jekla je ravnost jeklene plošče. To je eden od razlogov, zakaj je potrebno opisati in razumeti postopek deformiranja plošče med njenim ohlajanjem. Razporeditev temperature ima glavni vpliv na deformacijo traku. Na razporeditev temperature vpliva proces ohlajanja. Homogenost ali nehomogenost hlajenja je najpomembnejši faktor, ki vpliva na končno ravnost ohlajenega traku ali plošče. Nehomogeno hlajenje lahko povzroči velike razlike v razporeditvi toplote znotraj materiala in tudi velike deformacije. Na homogenost hlajenja najbolj vpliva razporeditev vode v področju hlajenja. Namen tega članka je eksperimentalni in numerični študij ter opis procesa deformacije vroče jeklene plošče med procesom hlajenja. Za dosego namena so bile eksperimentalno izmerjene hlajene jeklene plošče in dobljeni so bili mejni pogoji in temperaturno polje $\mathrm{Na}$ osnovi teh podatkov sta bila postavljena dva numerična modela. Prvi numerični model je bil osredotočen na proces hlajenja, simulacijo temperaturnega polja in pripravo vhodnih podatkov za naslednji korak. V naslednjem koraku je bil generiran drugi numerični model s pomočjo metode končnih elementov in simulirana je bila analiza strukture ter deformacije jeklene plošče. Opis deformacije oblike ohlajanih jeklenih plošč naj bi omogočil boljšo ravnost končnih proizvodov.

Ključne besede: proces hlajenja, deformacija, ravnost, numerična simulacija

\section{INTRODUCTION}

The flatness of a hot steel plate or strip is an important issue of heat treatment in the steel industry. POSCO Korea is also dealing with this problem. The flatness of a final product has a significant impact on the quality and price of the strip. The flatness of a steel plate is mainly affected by the water distribution and cooling homogeneity during the quenching process. Two important non-homogeneous types of water distribution can occur. The first type of non-homogeneity is caused by different intensities of the cooling from the top and bottom sides of a steel plate. The second type of non-homogeneity during a cooling process is created by different water distributions in the center and corners of a steel plate. Both of these types can occur simultaneously and produce problems with regard to the flatness of a steel plate $^{1,2}$. Non-homogeneous cooling also affects other aspects such as material properties, phase changes, residual stresses and so on ${ }^{3-5}$. The combination of all the aspects has a significant impact on the final quality of a steel plate and, therefore, the cooling process must be studied. The description of the cooling process can be performed using several parameters, including the cooling intensity, the distribution of the heat-transfer coefficient (HTC) and so on ${ }^{6,7}$. Experimental measurements were carried out at defined conditions to describe the cooling process and non-homogeneity identification during the quenching. The HTC distribution was obtained from the results and a model of the steel-surface thermal field was prepared. The inverse problem with a sequential estimation of the time and varying boundary conditions was used to simulate the cooling process and time-dependent boundary conditions ${ }^{8}$. The calculated thermal field of the steel plate was used in the next numerical simulation. This numerical simulation was 


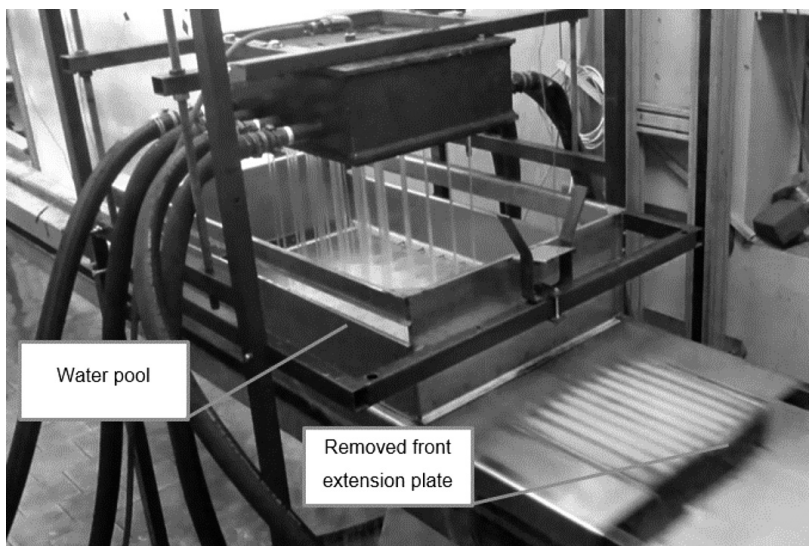

Figure 1: Experimental apparatus

Slika 1: Eksperimentalna naprava

focused on steel-plate deformations and an analysis of the flatness. The numerical simulation was based on the finite-element method in Ansys, a commercial software program.

\section{EXPERIMENTAL MEASUREMENT OF COOLING HOMOGENEITY}

The cooling process under defined conditions was experimentally measured using a laboratory apparatus prepared in the Heat Transfer and Fluid Flow Laboratory. The experimental apparatus is shown in Figure 1. The experimental measurements were focused on the study of the cooling non-homogeneity in the longitudinal and transverse directions of the test plate and also of the differences in the water distribution from the top and bottom sides.

A test plate equipped with three thermocouple sensors was used to investigate the heat transfer in the longitudinal and transverse directions. A schematic of the experimental measurement is depicted in Figure 2. The thermocouples recorded the temperature history during the cooling process and, using an inverse analysis, the surface temperatures and heat-transfer coefficients were computed. Both the upper and lower surfaces were investigated.

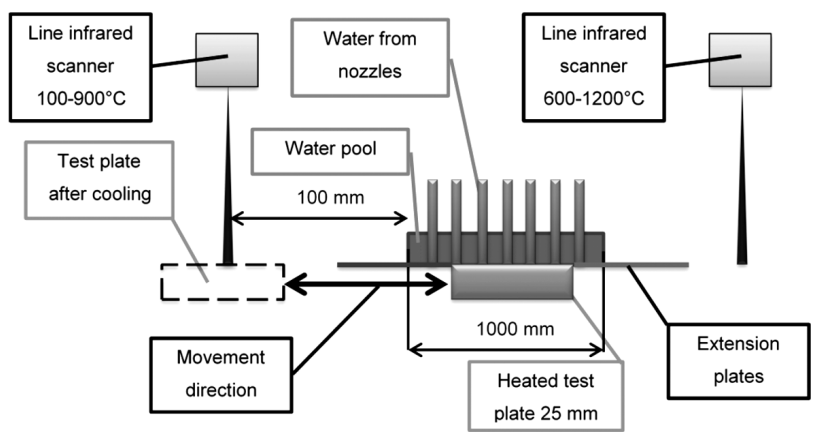

Figure 2: Schematic illustration of the experimental measurement Slika 2: Shematičen prikaz izvedbe meritev
The measurements were performed for several conditions. The examples of the experimental conditions are presented in Table 1. For the cooling from the top, a pool with an adjustable height was used to set the proper water layer.

Table 1: Examples of the measurement conditions

Tabela 1: Primeri pogojev pri meritvah

\begin{tabular}{|c|c|c|c|c|}
\hline Surface & $\begin{array}{c}\text { Spray distance } \\
(\mathrm{mm})\end{array}$ & $\begin{array}{c}\text { Flow rate } \\
\left(\mathrm{m}^{3} / \mathrm{min}\right)\end{array}$ & $\begin{array}{c}\text { Water layer } \\
(\mathrm{mm})\end{array}$ & $\begin{array}{c}\text { Velocity } \\
(\mathrm{m} / \mathrm{s})\end{array}$ \\
\hline Top & 400 & 3.0 & 54 & 0.8 \\
\hline Top & 400 & 4.5 & 65 & 0.8 \\
\hline Bottom & 50 & 3.0 & - & 0.8 \\
\hline Bottom & 50 & 5.3 & - & 0.8 \\
\hline
\end{tabular}

The temperature history recorded during the experiment was used to compute the time-dependent boundary conditions. These boundary conditions were computed using the sequential estimation of the time-varying boundary conditions and the HTCs were obtained using the inverse solution of the problem for each measurement. Using the applied calculation methodology, the HTC distribution on the steel plate was obtained. The evaluated data for the full temperature range of the experiments performed for the upper and lower cooling are shown in Figure 3. These figures represent the HTC distribution as a function of the surface temperature and the position.
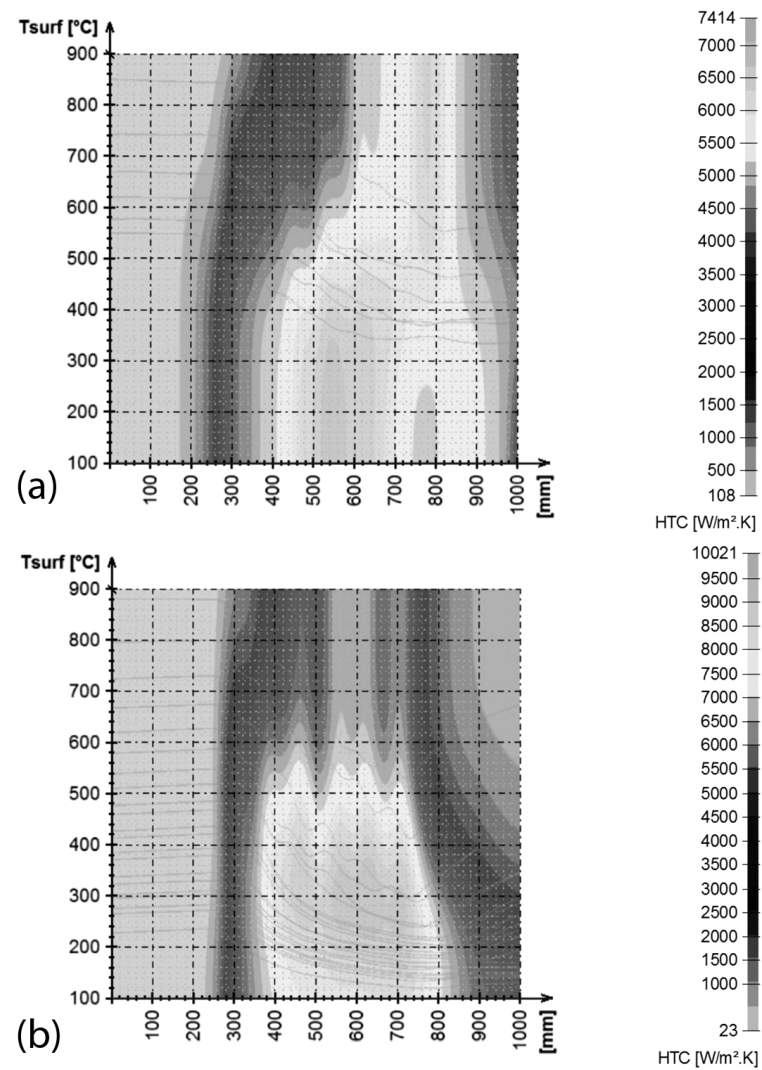

(b)

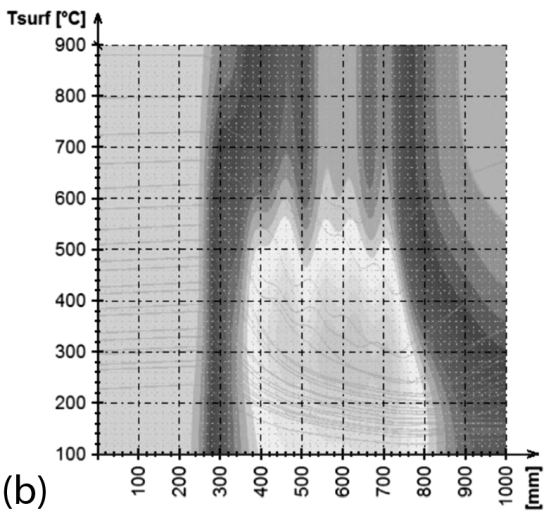

Figure 3: HTC distribution for: a) upper and b) bottom cooling Slika 3: HTC-razporeditev za hlajenje: a) zgoraj in b) spodaj 


\section{NUMERICAL SIMULATION}

The numerical simulation was prepared in two steps. In the first step, a numerical model of the thermal field was prepared. In this step, FDM methods were considered as the solver for the heat conduction. The second step was focused on the preparation of the numerical model for the structural analysis of the steel plate. The second numerical model was based on the FEM.

\subsection{Temperature-field simulation}

A cooling test plate was simulated to verify the HTC values obtained with the laboratory measurements. The selected discretization equations obtained using the FDM have a clear physical meaning - they are not simply a formal mathematical approximation. The derived equations represent the conservation principles (mainly the energy conservation) for each control volume and the resulting numerical solution correctly satisfies the conservation over the whole calculation domain. As the conductivities of the neighboring volumes may be different due to the different temperature, there may be a discontinuity of the slope $(\mathrm{d} T / \mathrm{d} x)$ at the control volume boundary. Whenever there is a need to get the temperature at a control volume boundary (e.g., during the interpolation of the temperature across the control volume), a detailed equation should be used together with the temperature at the node.

When the mass density or specific heat becomes more dependent on the temperature, special care must be paid to the time integration: if the time step is too large, the latent heat of the phase change may be neglected. In the case of a phase change, the properties are highly dependent on the temperature. This problem can be eliminated by solving it using the enthalpy instead of the specific heat and the mass density. The approach that was used and overcomes this problem was inspired by the apparent-heat-capacity method.

The boundary conditions were prepared from the data presented in the previous section (Figure 3). The data was considered as a function of three variables: HTC

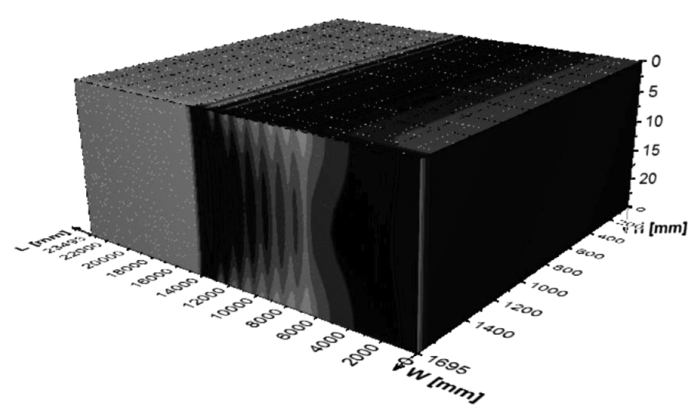

Figure 4: Temperature profile (different scales on the axes) Slika 4: Profil temperature (različna merila po oseh)
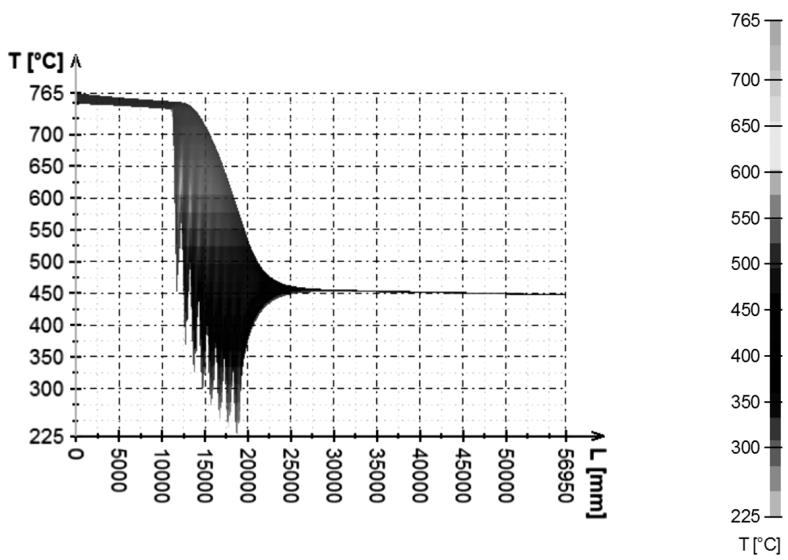

Figure 5: Center and surface temperature histories in the middle of the plane

Slika 5: Temperaturna zgodovina sredine in površine na sredini površine

(length, $T_{\text {surface, }}$ width). An example of the applied boundary conditions at a time of $32 \mathrm{~s}$ for the upper cooling of the test plate is shown in Figure 4.

The computed temperature histories for the entire cooling process are shown in Figure 5. This figure indicates a large temperature difference between the surface and the center of the plate in the middle of the plate. The applied method for the temperature-field simulation agrees with the plant measurements.

\subsection{Simulation of deformation}

This section contains the structural analysis of the steel plate focusing on the deformations. The measured thermal loading produced by the simulated cooling process was described in the previous chapter. The purpose of this calculation was to assess the impact of the cooling process on the deformation of the steel plate produced experimentally.

The calculation methodology for the structural analysis of the FE model consists of three steps. In the first step, the 3D finite-element model was created with respect to the real dimensions and conditions. In the second step, the calculated temperature field, the structural boundary conditions and the initial conditions were applied. In the final step, the analysis of the structure and deformation of the steel plate was calculated. Two types of loads were considered for the prepared FE model: the experimentally measured thermal field as the thermal load and the mechanical loads represented by the movement of the plate. The analysis of the steel-plate deformation due to different conditions was carried out for two cases. In the first case, the specimen was tested under measured cooling conditions, and the second case was the same as the first case (the same cooling conditions) but without considering the gravity. The case without the gravity acceleration was performed to obtain the true deformation due to the cooling process. 


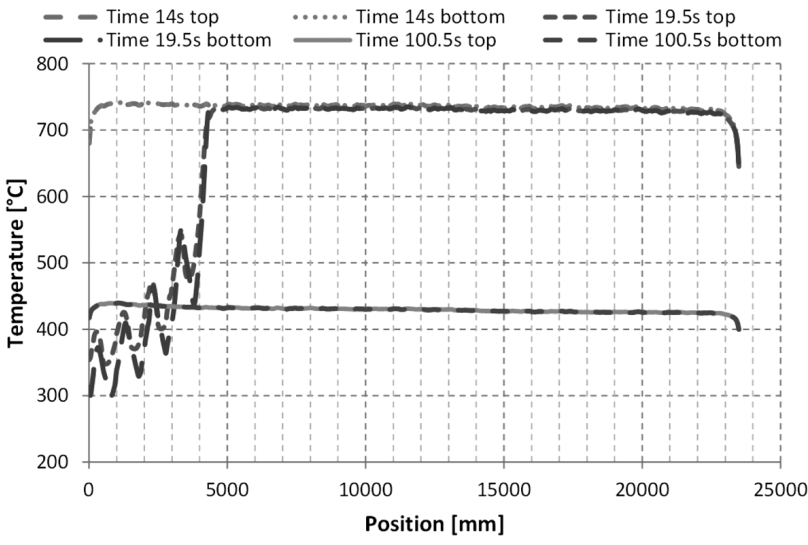

Figure 6: Evaluated temperatures through the path at defined time points

Slika 6: Ocenjene temperature skozi sredino, $\mathrm{v}$ določenih časovnih trenutkih

The thermal loads were FDM analyzed and applied as the body loads of the steel plate. The temperature was evaluated at the center of the steel plate along a defined path (the symmetry plane) on the top and bottom sides. The evaluation of the temperature distribution along the defined path is shown in Figure 6. The temperature distributions (Figure 6) show that at the beginning (14 s) and at the end of the cooling (100.5 s), the top and bottom temperatures are almost equal. At a time of $19.5 \mathrm{~s}$ it is clear that the cooling is less intense on the top and that the bottom temperatures are lower.

Different values of the temperature on both sides of the steel plate lead to different stresses and deformations. The presented thermal field was used for the structural analysis and the deformation of the steel plate was calculated. The final vertical deformation at the end of the cooling reached $2.8 \mathrm{~mm}$. The maximum vertical deformation is located at the corner of the steel plate.

The deformation of the steel plate along the path at the corner and along the path at the center was evaluated (Figure 7). The comparison of these two locations confirmed two reasons for the maximum deformation in

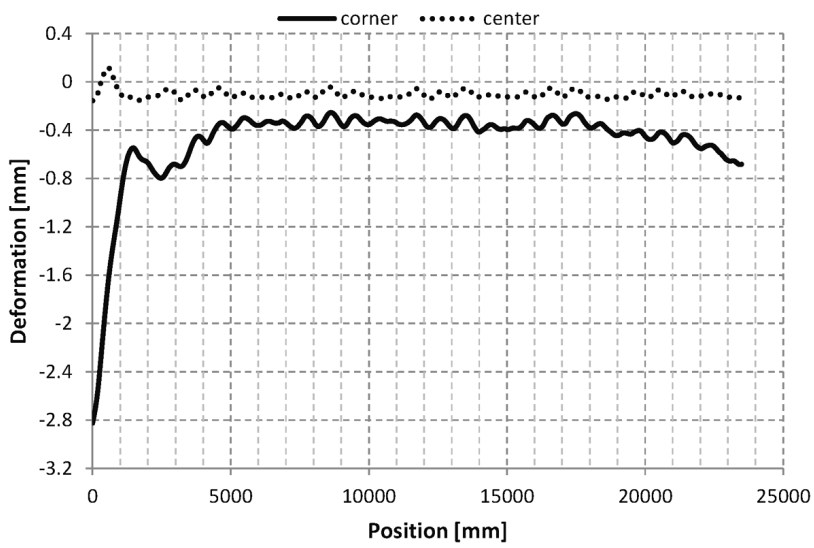

Figure 7: Evaluation of the total vertical deformation at a time of $100.5 \mathrm{~s}$

Slika 7: Ocena skupne vertikalne deformacije pri času 100,5 s the corner. The first reason is the non-homogeneous thermal field at the corner. The second reason is that the corner is free and a deformation is possible. In the center, the steel plate is constrained by the symmetry (in reality the steel plate would continue). The gravitational acceleration contributes to a decrease in the total deformation.

For the second case, the same type of cooling as for the first case was used and the gravitational acceleration was not considered. The final vertical deformation at the end of the cooling reached $596 \mathrm{~mm}$. The maximum vertical deformation is located symmetrically at the beginning of the steel plate. The deformations of the steel plate in this case are mainly affected by the thermal distribution and the thermal gradients.

The presented deformation results confirm that the more intense cooling from the bottom side of the steel plate leads to the final deformation on the lower-cooling side of the steel plate (the top side). This effect can be explained with the following mechanism. On the bottom side, which is cooled more intensely, the temperature drops quickly and the stiffness $(K)$ represented by the modulus of elasticity $(E)$ of the bottom layer is changed to a higher value. In the middle part of the steel plate, the temperature is still high and the stiffness is low (the modulus of elasticity at a higher temperature). On the top side of the steel plate, the temperature also decreases but not as intensely as on the bottom side. The stiffness of the top layer is lower than the stiffness of the bottom layer.

The combination of the temperature and the stiffness distribution of defined layers leads to different directions of the deflection $(U)$ in each layer. The highest deflection in the axial direction of the steel plate is in the middle layer due to the higher temperature and thermal expan-
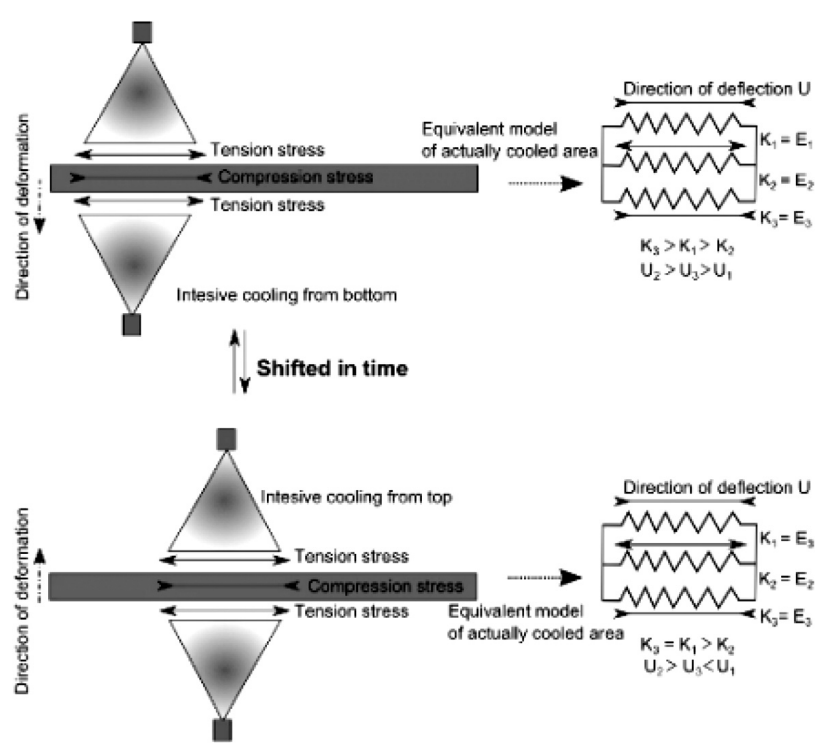

Figure 8: Schematic illustration of the steel-plate deformation mechanism

Slika 8: Shematičen prikaz mehanizma deformacije plošče iz jekla 
sion. On the bottom side of the steel plate, deflection occurs in the opposite direction than in the middle layer due to intense cooling. At the top layer, the lower cooling intensity leads to a deflection in the same direction as at the bottom layer, but the deflection is lower than on the bottom side. These deflection distributions through the thickness of the steel plate generate a deformation in the intensely cooled side direction.

Non-homogeneous cooling on the bottom and top sides of the steel plate cause a time shift in the temperature distribution on both sides. The time shift in the temperatures on both sides causes a deflection inverted from the bottom and top layers, changing the final deformation of the steel plate in the direction of the actual cooled side (the top side). A schematic illustration of the deformation of the steel mechanism due to non-homogeneous cooling is depicted in Figure 8. The elasticplastic material properties of steel are considered in the numerical model and, therefore, a permanent deformation occurs.

\section{CONCLUSION}

The analyses presented in this paper focused on the study of non-homogeneous cooling and its impact on the deformation of a steel plate. Several numerical models of steel plates were prepared. The first model computed time-dependent temperature fields. Plant measurements were simulated using this model. The results obtained from the simulation agree with data obtained during the plant measurements. The second numerical model focused on the cooling process of the steel plate and the impact of thermal fields on the final deformations of the steel plate. The FE simulation of the cooling process showed the impact of the non-homogeneity in the thermal field on the final deformations. The simulations confirmed that the plate is bent towards the side with the higher cooling intensity in the initial cooling stage; however, in the later stages, the plate is bent towards the opposite side, with the lower cooling intensity.

\section{Acknowledgement}

The paper presented was supported through project CZ.1.07/2.3.00/30.0005 of the Brno University of Technology.

This work is an output of the research and scientific activities of the NETME Centre, regional R\&D center built with the financial support from the Operational Programme Research and Development for Innovations within the project NETME Centre (New Technologies for Mechanical Engineering), Reg. No. CZ.1.05/2.1.00/ 01.0002 and, in the follow-up sustainability stage, supported through NETME CENTRE PLUS (LO1202) by the financial means from the Ministry of Education, Youth and Sports under the National Sustainability Programme I.

\section{REFERENCES}

${ }^{1}$ X. Wang, Q. Yang, A. He, Calculation of thermal stress affecting strip flatness change during run-out table cooling in hot steel strip rolling, Journal of Materials Processing Technology, 207 (2008), 130-146, doi:10.1016/j.jmatprotec.2007.12.076

${ }^{2}$ Y. J. Jung, G. T. Lee, C. G. Kang, Coupled thermal deformation analysis considering strip tension and with/without strip crown in coiling process of cold rolled strip, Journal of Materials Processing Technology, 130-131 (2002), 195-201, doi:10.1016/S0924-0136 (02)00705-7

${ }^{3}$ H. N. Han, J. K. Lee, H. J. Kim, Y. S. Jin, A model for deformation, temperature and phase transformation behavior of steel on run-out table in hot strip mill, Journal of Materials Processing Technology, 128 (2002), 216-225, doi:10.1016/S0924-0136(02)00454-5

${ }^{4}$ X. Wang, F. Li, Q. Yang, A. He, FEM analysis for residual stress prediction in hot rolled steel strip during the run-out table cooling, Applied Mathematical Modelling, 37 (2013), 586-609, doi:10.1016/ j.apm.2012.02.042

${ }^{5}$ S. Serajzadeh, Prediction of temperature distribution and phase transformation on the run-out table in the process of hot strip rolling, Applied Mathematical Modelling, 27 (2003), 861-875, doi:10.1016/ S0307-904X(03)00085-4

${ }^{6}$ M. Chabicovsky, M. Raudensky, Experimental Investigation of a Heat Transfer Coefficient, Mater. Tehnol., 47 (2013) 3, 395-398

${ }^{7}$ M. Raudensky, Heat Transfer Coefficient Estimation by Inverse Conduction Algorithm, International Journal of Numerical Methods for Heat and Fluid Flow, 3 (1993) 3, 257-266, doi:10.1108/eb017530

${ }^{8}$ M. Pohanka, P. Kotrbacek, Design of cooling units for heat treatment, In: F. Czerwinski (Ed.), Heat Treatment - Conventional and Novel Applications, InTech, 2012, 1-20, doi:10.5772/50492 